\section{Green protectionism and the Need for Harmonisation}

\section{Eine wesentliche Triebkraft der Harmonisierung in der Europäischen Union ist die Schaffung eines gemeinsame Binnenmarktes. Umweltpolitische Maßnahmen stellen vielfach ein Problem für diese Harmonisierungsprozesse dar. Am Beispiel der Verpackungspolitiken Deutschlands und Dänemarks wird aufgezeigt, wie die ökologischen Argumente zugleich einen Schułz öko- nomischer Interessen darstellen. Es wird die These vertreten, daß inzwischen letzteres überwiegt und wissenschaftliche Erklärungsversuche wie Ökobilanzen hierfür instrumentalisiert werden. Ökonomische Harmonisierungsforderungen erscheinen daher gerechtfertigt.}

$\mathrm{E}$

Von Nicolas Buclet conomic exchanges - whether in terms of trade, investments or mergers and acquisitions - are particularly intense between European Union member states. This intensity is growing with the ongoing process of European integration. Free trade has rapidly become the leading principle in this process, even at a wider scale than that of the EU, under GATT/WTO. Moreover, the main aim of the European Union has been since the Treaty of Rome to create a single market based on the free movement of goods, services, capital and workers and especially on an undistorted competition within the EU. Therefore harmonisation of rules and standards is one of the main issues of European Union legislation,

The increasing level of economic activities, and their expanding geographic scale, are the cause of increasing environmental impacts, in particular those caused by the handling of increasing volumes of waste. National governments developed policies, and adopted legislation, aimed at controlling the environmental effects of waste. In this realm, environmental protection has become the leading principle. However, many measures taken by national governments infringe, intentionally or not, on the principle of free trade. The objective of environmental protection is then in conflict with the principle of free trade.

Our purpose here is not to concentrate on the whole question of free trade, but on the part of this question involved with consumer products and the special case of packaging waste. In this domain, the Danish bottle case and the German deposit refund system are two examples which demonstrate the problem. Both cases had a big influence on the setting of a ,packaging" directive $(94 / 62 / \mathrm{CE})$ of the $\mathrm{EU}$.

\section{The Danish case}

In Denmark, the practice of the deposit of bottles, in particular for beers and soft drinks, has never been interrupted. Already in the sixties, an environmental regulation reinforced the economic reasons of its existence. Danish authorities, in accordance with existing knowledge and techniques, banned metal cans from the domestic market. Given the existing techniques and knowledge, they considered the deposit of glass bottles as preferable from an environmental point of view. No Danish actors really contested the choice. From this time onwards, itself from the other European countries. Afterwards, regulations were adopted at the beginning of the eighties in order to stabilise a practice threatened by the evolution of distribution in all industrialised countries. Indeed, globalisation of markets induces firms in the beverage sector to use one-way packaging.

By obliging beverage producers to use refillable packaging, the regulator perpetuates a system considered as overtaken by non-Danish multinational firms of the sector, but already well integrated in the strategy of Danish firms. Firms like Carlsberg and Tuborg, incontestable leaders of the Danish market of beer, have not ceased to commercialise their production beverage distribution in Denmark distinguishes destined to the domestic market, with deposited bottles. At the same time, these firms adapted themselves to their markets for export, and sell beer in metal cans. By this way, Danish firms maintain the quasi-exclusive control of their domestic market while they entered on outside markets.

This situation has been judged inequitable by foreign producers and incited them to put pressure on the European Commission to file a complaint, at the European Court of Justice (ECJ), on the basis of article 30 of the Treaty of Rome and of the respect of free-trade.

The Commission argued that the incriminated regulation constitutes a measure with an effect equivalent to a quantitative restriction, which cannot be justified by an imperative requirement of environmental protection. Furthermore it is a measure with discriminatory effects against imports. Finally there exists a regulation of the EU regarding packaging for liquid foodstuffs. The Commission argued that this directive of 1985 provided the same environmental effectiveness, but with less restrictive means for the intra-communitary trade.

Denmark asserts that it is not the only Member State to say that the directive of 1985 does not propose the most efficient solutions. The Danish system is, according to the national authorities, superior as regards the rate of reuse, volume of waste, and management costs. Only when an alternative solution as efficient as its own is proposed to Denmark, will it accept to revolve the legislation on packaging. Furthermore the agreement should not obstruct importers and foreign producers to enter into the Danish market.

The ECJ stated that ,in the absence of a common regulation regarding the production and the marketing of the concerned products", measures with restrictive consequences on free-trade are acceptable, from the moment that it turns out that they are ,necessary in order to satisfy imperative general interest requirements..." (1). However, such measures have to be applied indistinctly to national and imported products. In this particular case, it has been judged that ,the environmental protection constitutes an imperative requirement, which may limit the implementation of the article 30 of the treaty". The decision of the ECJ of the 20th of September 1988 proved Denmark to be right in the absence of a European regulation insuring the same level of environmental protection. 


\section{The consequences}

We note that the debate on the environmental superiority of a system on another is turning quite rapidly into a confrontation of divergent interests between industrialists. Is environment a pretext for protectionism for Denmark? Can free-trade, defended by multinational firms, and sustained by the European institutions, justify the renunciation of a system accepted by the majority of the population, and which has proved in the eyes of a whole country to be positive for the environment?

\section{A game-theoretic analysis}

It is a game-theoretic scenario and especially the measure of the risks of drift, in one sense or another, which can help to solve the problem. On the one hand, we can wonder if Danish brewers would keep the same position regarding deposits if the whole European countries adopted the Danish system. It is likely that the effect for them would be the loss of market-shares abroad. But the generalisation of the Danish system in Europe, only threat likely to generate effects with an eventual sentence of the European Court of Justice, does not seem credible, because it is against the interests of most nonDanish brewers. In a non-co-operative logic between European countries, it seems that the game is in favour of Danish brewers.

The generalisation of the deposit system in Europe would cost a lot, and the gain of the market share of non-Danish brewers would probably not compensate such costs. Moreover, Danish brewers are interested in maintaining the status quo. The order of the sequences of the game is not at random. If they want to change the situation, non-Danish brewers have to move first. But wouldn't it be an action, which would penalise themselves? Even if Danish brewers would loose proportionally more than their competitors, the wish of a generalisation of a deposit system would have to be justified with the regulator and the opinion by environmental arguments.

If, afterwards, Danish brewers would admit having lost the game and also wish the complete dismantling of deposit systems in Europe, this could not be done without several problems. Besides the costs bound to the reorganisation of the production process, how can one justify a new renunciation of deposit after having sung its ecological praises and having pushed its reintroduction? Which regulator and which opinion would accept such a reversal? For such reasons, the big European brewers do not have a credible threat, if not through the European institutions. As, besides, no change in the position of the European Court of Justice is conceivable as long as a European directive will not prove to be more efficient for domestic waste management, we can understand one of the important points of the „packaging“ directive. Such a directive is required in order to prevent proliferation of national environmental measures which would have the effect of bringing more or less intense restrictions to free trade inside the European market. The degree of the restrictions issued from this type of measure does not need to be important. Its impact, as in the Danish case, expresses itself as a symbol. The „European Commission-Denmark" case has become important as a juridical precedent. The protection of the environment is promoted to the range of an imperative requirement, which can prevail on the principle of free trade. As a juridical precedent, it may favour the adoption of other ,barriers" to free trade, with high effect this time.

In fact, after long debates an European packaging directive has been installed in 1994 (62/94/CE). This directive aims at harmonising national packaging waste management measures, minimising environmental impacts of packaging waste and at avoiding the erection of barriers to trade within the EU. Similar to the German regulation, quotas are an important element. 50-65 per cent of packaging waste must be recovered (included incineration with energy recovery), and 25-45 per cent of all packaging waste must be recycled with at least 15 per cent of each packaging material being recycled. In fact, the directive is based on the article $100 \mathrm{a}$ concerning the single European market and not on the environmental Article 130s. Industry thus succeeded in making the protection of free trade the priority. Some more far reaching environmental aims were dropped within the decision-making process not least because of the spill-overs (exports) of packaging waste by the German DSD system, the second example to be considered in the following.

Nevertheless, there is still controversy if this directive is sufficient to fullfill the ECJ's requirements of a common regulation, even though the Danish system came again under attack after the implementation of the packaging directive.

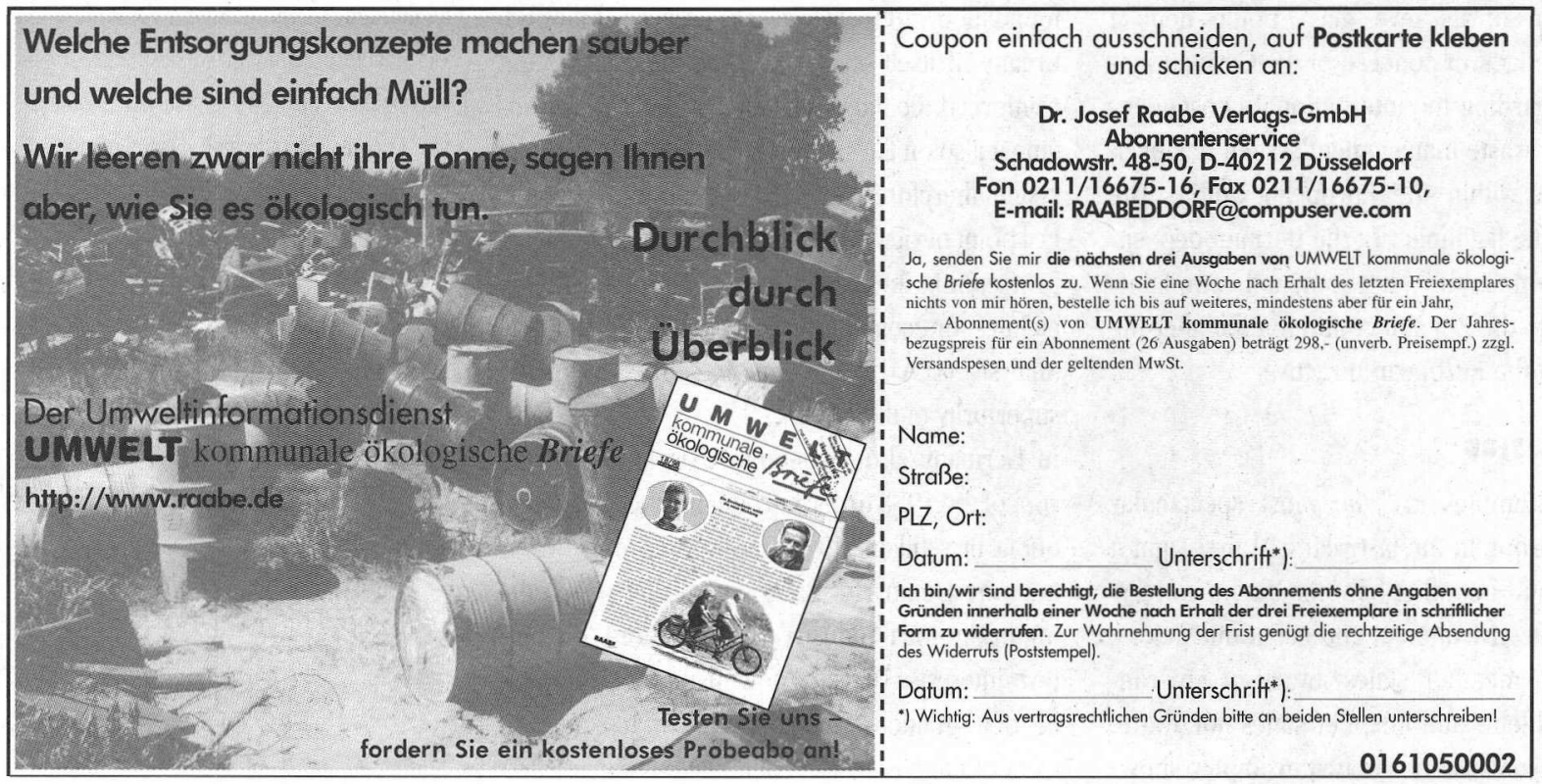




\section{The German system of deposit-refund}

The option taken in Germany regarding household waste management, and particularly on beverage packaging, has hurt several industrials, mostly foreign firms with commercial interests within the country. They consider the measures taken (take-back obligation for packaging and quota for refillable) an violation of the free-trade principle established between European countries and denounce it as ,disguised protectionism". An intense debate has arisen on this question between industry, European institutions and German public authorities. We will not explain the nature of such measures here (2), but rather analyse the conflicts that it raises.

The provisions concerning beverage packaging are often interpreted as ,disguised protectionism", aiming to favour small Bavarian bottlers and brewers. In this Land, indeed, an important number of brewers commercialise their products in deposited glass bottles. In 1991, Bavaria had been the only Land to vote against the so called ,Verpackungsverordnung“, because it did not completely prohibit one-way packaging for beer, mineral water and milk.

Foreign producers of beverage do not view the legislation on refillable packaging favourably. According to them, it goes against the free-trade principle. It would favour local industry to the detriment of the others. The case of Evian, which sold 43 millions bottles of 1.5 litre in 1988, and only 5.9 millions bottles in 1990 (3), illustrates quite well the difficulties met by a firm geographically too far from the market to consider the organisation of its own glass bottle deposit system. The lack of concern of the German authorities regarding the international consequences of their waste management system has been sharply felt within the European Union. The debate on the legitimacy of the German depositrefund scheme is still a hot spot, and complaints addressed to the ECJ still continue even after the adoption of the European directive.

\section{> Conclusion}

The two examples are the most spectacular faced in Europe in the last years. At first sight it is a question of conflict between actors concerned with the environment and economic actors, or between member states aware of environmental problems and member states not aware. Yet, the observation of the two examples shows that the firms involved belonging to the countries having adopted the incriminated systems, are maybe their stronger defenders. The opposition is therefore not environment against economy. This is not as surprising as it could seem. We have to distinguish two elements regarding the cases of measures supported by domestic firms against firms from abroad: the genesis of the system at the source of the conflict; the measures taken in a second time in order to protect such a system.

At the origin these systems have been established for several reasons. Generally deposit-refund schemes were born for economic reasons. Firms had interest in refill their own bottles. The structure of the market of beverage was essentially local. In the sixties, this was still the case when Denmark introduced the ban on metal and aluminium cans for environmental reasons. There was surely no intention to introduce a measure aiming at protecting the market from abroad. The bias came with the evolution of the beverage market: an increasing openness to producers more and more far from the consumers, thanks to the introduction of packaging loosing weight with time. The economic advantage of refilling bottles was disappearing.

At the beginning of the eighties, deposit-refund systems were still alive throughout Europe but to a very different degree. The size of the country had surely an influence on this.

Whatever the reasons, in these regions the market still left room to deposit-refund schemes and local industry has organised itself on this basis. In Denmark, added to the ban on metal and aluminium cans, environmental reasons were the main foundation of the system. The industry followed, organised itself on the basis of the system, and reinforced the interest of the country for it, bringing it also on the economic field. Maintaining the system therefore also became important from this last point of view. The various measures, aiming at protecting a threatened system, came during the eighties for economic reasons, while no Life Cycle Analysis (LCA) was really able to assert of the superiority of the system.

In Germany also, economic reasons are at the root of the 1988 order introducing the 72 percent quota of refillable. It is maybe even more clear than in Denmark. Bavarian retailers and the important local industry of beer feared for their own interests. They are now insured of the stability of a situation, which allows them to survive in front of the biggest food and drink companies.
The debate continues on the ground of environmental arguments, each part arguing with the results of LCAs and of other methods in order to support their own position. The controversy on LCAs is far from being closed. In the end, it is most of all a question of social preferences, which has to be expressed also on a non rational basis. A region in Europe still has the possibility to defend its own deposit-refund schemes, thanks to the subsistence of scientific controversy (4). Yet, we should be aware that the main stake is now economic and that environment is instrumentalised by economic interests.

\section{References}

(1) This argument follows the lines of the famous "cassis de Dijon" judgement of the ECJ.

(2) See Buclet N., Godard 0 (eds.): Municipal Waste Management in Europe: A Comparative Study in Regime Building, ed. Kluwer, Dordrecht/London, forthcoming.

(3) The fall of sales can be explained by the introduction, in 1988, of an obligatory deposit of 0.25 ECU on one-way plastic bottles, which have to be taken back by the retail sector and have to be re-used or recycled by the distributors. Because big retailers did not want to establish a second system in order to take back one-way bottles, they stopped in 1989 and 1990 to sell them. The situation. evolved with the order of 1991 which imposed a general objective to the beverage sector (at least 72 percent of bottles have to be refilled) and not an objective for every brand sold on the market. The compulsory deposit of 0.25 ECU does not exist anymore.

For further details on the Evian case, see

Buclet. N.: Politiques d'environnement, trajectoires institutionnelles et contraintes de coordination internationale: le cas des déchets d'emballages ménagers en Europe, Thèse de doctorat, Université Paris VII, 1997.

(4) Godard 0.: Stratégies industrielles et conventions d'environnement: de l'univers stabilisé aux univers controversés. Congrès international "Environnement et économie: de I'univers stabilisé aux univers controversés", Ministère de I'Environnement, INSEE, IFEN, Paris, 15-16 Février 1993.

\section{Der Autor}

Dr. Nicolas Buclet ist Forscher am International Cent re for Research on Environment and Development (CIRED), Paris.

Kontakt: CIRED, 45 bis Avenue de la Belle Gabrielle Jardin Tropical, F-94736 Nagent-sur-Marne Cedex, Tel. 0033-1-439473-73, Fax -70, E-muil: buclet@centre-cired.fr 
(c) 20I0 Authors; licensee IÖW and oekom verlag. This is an article distributed under the terms of the Creative Commons Attribution Non-Commercial No Derivates License (http://creativecommons.org/licenses/by-nc-nd/3.o/), which permits unrestricted use, distribution, and reproduction in any medium, provided the original work is properly cited. 